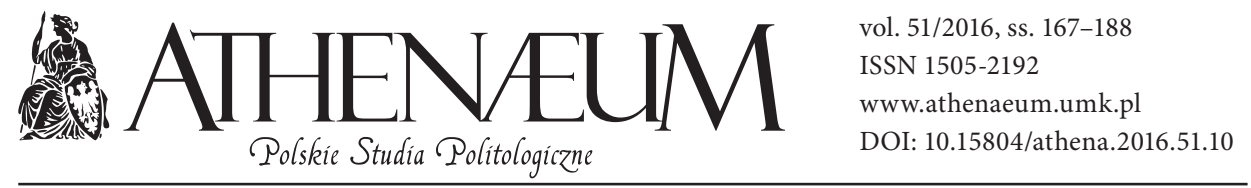

\title{
DIAGNOZA I OCENA POZIOMU KAPITAŁU SPOŁECZNEGO WOJEWÓDZTWA ŚWIĘTOKRZYSKIEGO
}

\author{
THE DIAGNOSIS AND ASSESSMENT OF SOCIAL CAPITAL \\ OF THE ŚWIĘTOKRZYSKIE REGION
}

\author{
Sławomir Pastuszka*
}

\begin{abstract}
ABSTRAKT
Celem artykułu jest ocena poziomu kapitału społecznego województwa świętokrzyskiego. Analizie poddano takie elementy, jak: zaufanie, odpowiedzialność za dobro wspólne, skłonność do zrzeszania się oraz deklarowaną aktywność społeczną, udział w wyborach władz. Do analizy wykorzystano badanie ankietowe przeprowadzone wśród mieszkańców województwa świętokrzyskiego pod koniec 2014 r. Zdiagnozowany poziom kapitału społecznego badanych osób nie napawa optymizmem - cechuje go niski stopień zaufania ogólnego, stosunkowo niewielkie zaangażowanie w inicjatywy na rzecz dobra wspólnego oraz małe zainteresowanie aktywnością organizacji społecznych. Takie postawy i zachowania prawdopodobnie wpłyną negatywnie na perspektywy rozwoju gospodarki regionalnej opartej na wiedzy, spowolnią postęp społeczny, a w efekcie utrudnią zwiększenie poziomu dobrobytu mieszkańców województwa świętokrzyskiego.
\end{abstract}

Słowa kluczowe: kapitał społeczny, zaufanie, współpraca, aktywność społeczna, województwo świętokrzyskie
The article examines the level of social capital of the Swiętokrzyskie Voivodeship. The analysis included such items as: trust, responsibility for the common good, the tendency to association, declared social activity, and participation in elections authorities. As a basis of the examination there was used the questionnaire conducted among residents of the Świętokrzyskie region at the end of 2014. Diagnosed level of social capital is not optimistic - surveyed people are characterized by a low level of general trust, limited involvement in initiatives for the common good and little interest in the activity of public organizations. Such attitudes and behaviors likely will negatively affect the prospects of the development of the regional development based on knowledge, will slow down the social progress, and consequently will make it more difficult to increase the well-being of the inhabitants of the Świętokrzyskie region.

Keywords: social capital, trust, cooperation, social activity, the Świętokrzyskie region

\footnotetext{
* Uniwersytet Jana Kochanowskiego w Kielcach, Wydział Prawa, Zarządzania i Administracji.
} 


\section{WPROWADZENIE}

Kapitał społeczny uznawany jest za jeden $\mathrm{z}$ ważniejszych zasobów rozwojowych społeczeństw. Ma zasadnicze znaczenie dla prawidłowego funkcjonowania instytucji ekonomicznych, społecznych i politycznych. Służy integracji i solidarności społecznej, kształtowaniu ładu społeczno-moralnego, uzupełnianiu i wyręczaniu niewydolnych instytucji państwa, kontroli sektora rządowego i wymuszaniu jego odpowiedzialności, kontroli sektora komercyjnego (Czapiński, 2006, s. 9). Korzystnie wpływa na aktywność gospodarczą poprzez zmniejszenie kosztów transakcyjnych związanych z zabezpieczeniem umów i weryfikacją wiarygodności partnerów gospodarczych (North, 1990, s. 3; Williamson, 1998, s. 60). $\mathrm{Z}$ drugiej strony następstwem niskiego poziomu tego kapitału jest blokowanie aktywności obywatelskiej w jej najszerszym, społecznym wymiarze i kształtowanie przekonania o odpowiedzialności władz za warunki życia obywateli.

Podstawowym celem opracowania jest próba oceny poziomu kapitału społecznego województwa świętokrzyskiego, jednego z najsłabiej rozwiniętych w Polsce. Opracowanie składa się z pięciu części. Artykuł rozpoczynają rozważania dotyczące zakresu pojęciowego i sposobu pomiaru kapitału społecznego. Następnie omówiono formy, zalety i wady kapitału społecznego. W dalszej kolejności zaprezentowano metodologię badania ankietowego oraz charakterystykę badanych osób. Na tym tle omówiono wyniki badania, dokonano podsumowania zebranych informacji i podjęto próbę sformułowania najważniejszych wniosków. Rezultaty badania mają charakter zarówno poznawczy, jak i aplikacyjny. Poszerzają wiedzę teoretyczną na temat specyfiki społeczeństwa województwa świętokrzyskiego w kontekście teorii kapitału społecznego, a jednocześnie mogą stanowić przyczynek dla sformułowania wniosków dla polityki rozwoju województwa na lata 2016-2020 i zainicjować podjęcie w tym zakresie potrzebnych działań współfinansowanych ze środków publicznych, zwłaszcza z Unii Europejskiej.

\section{POJĘCIE, ZAKRES I MIARY KAPITAŁU SPOŁECZNEGO}

Kapitał społeczny, najogólniej rzecz ujmując, oznacza zdolność obywateli do aktywizacji i łączenia niezbędnych zasobów. Zdolność ta wzmacnia wolę współpracy i porozumienia w osiąganiu uzgodnionych celów. Istotą kapitału społecznego jest to, że przejawia się on w sieciach i relacjach społecznych. Po 
raz pierwszy tego pojęcia użył Lyda Judson Hanifan (1916, za: Putnam, 2008, s. 34). Jego zainteresowania były skupione na rozwiązaniach praktycznych mających wpływ na jakość nauczania w szkołach wiejskich. Według Hanifana kapitał społeczny kształtowany jest przez dobrą wolę poszczególnych ludzi, ich wzajemne relacje oraz umiejętność współpracy. Charakter tych relacji, zdaniem tego amerykańskiego wizytatora oświaty, jest uwarunkowany przede wszystkim akceptowanymi normami, wzorcami i wartościami, które obok konkretnych rozwiązań instytucjonalnych tworzą system infrastruktury społecznej.

Kategoria kapitału społecznego została rozpowszechniona w literaturze przedmiotu za sprawą Pierre’a Bourdieu, Jamesa Colemana, Roberta Putnama i Francisa Fukuyamy. Badacze ci różnie interpretowali zakres znaczeniowy kapitału społecznego. Pierre Bourdieu (1986, s. 248-249) kapitałem społecznym określał sumę możliwych do wykorzystania aktualnych i potencjalnych zasobów należących do jednostki bądź grupy z tytułu posiadanej sieci relacji i znajomości lub prościej - „sumę kapitałów i władzy”, którą jednostka lub grupa może zmobilizować dla realizacji wspólnie przyjętych celów. Według tego francuskiego socjologa kapitał społeczny jest dobrem prywatnym, a nie publicznym, i może owocować kapitałem kulturowym, zamożnością albo kapitałem symbolicznym (kompetencje, umiejętności), czyli oznakami statusu społecznego. Choć teoretycznie posiadany kapitał społeczny może rekompensować braki innych typów kapitału, to działa tu zasada kumulatywnej przyczynowości. Osoby dysponujące kapitałem społecznym łatwiej mogą powiększać zasoby innych kapitałów (kulturowego i ekonomicznego), i odwrotnie - dysponowanie innymi kapitałami najczęściej wynika z odpowiednich sieci znajomości.

Odmienne podejście do kapitału społecznego zaproponował James Coleman. Uważał on, że ten rodzaj kapitału nie jest prywatną własnością osób czerpiących z niego korzyści, jak twierdzi Bourdieu, ale zasobem danej społeczności powiązanej sieciami relacji. Umożliwia on osiąganie celów, które nie mogłyby zostać osiągnięte w przypadku jego nieobecności, a jeśli już, to pod warunkiem poniesienia wyższych kosztów. Zdaniem Colemana (1988, s. 95-120) inwestycja w kapitał rzeczowy przynosi materialne korzyści inwestorowi, inwestycja w kapitał ludzki zwiększa jego wiedzę i kwalifikacje, natomiast inwestycja w kapitał społeczny daje jednostce tylko cząstkę ogólnych korzyści.

Istotną cechą kapitału społecznego jest przechodniość zaufania w społecznych sieciach zależności. Polega ona na tym, że w stabilnym systemie społecznym osobiste zaufanie (personalized trust) towarzyszące stałym i częstym bezpośrednim kontaktom jest przenoszone na poziom relacji osób, które mniej 
się znają lub w ogóle. W ten sposób kształtuje się zaufanie ogólne (generalized trust) - konieczne z punktu widzenia rozwoju gospodarczego. Dlatego w ocenie Colemana (1990, s. 302-305) grupa, której członkowie wykazują, że są godni zaufania i ufają innym, będzie w stanie osiągnąć znacznie więcej niż porównywalna grupa, w której występuje wzajemna nieufność.

Konceptualizację kapitału społecznego Colemana kontynuował Francis Fukuyama. Według niego (Fukuyama, 1997) kapitał społeczny oznacza zestaw wartości i norm etycznych wspólnych dla członków określonej grupy, umożliwiających im skuteczne współdziałanie. Przestrzeganie wspólnych norm i wartości moralnych jest warunkiem wzajemnego zaufania członków grupy, które sprzyja efektywności jej działania. Źródłem norm i wartości w każdym społeczeństwie jest kultura nierzadko ukształtowana przez religijną tradycję. Powiązanie między zaufaniem a kapitałem społecznym wyraża przedstawiona przez Fukuyamę koncepcja „kręgów zaufania” (radius of trust) ${ }^{1}$. Amerykański politolog i ekonomista przyjął, że społeczeństwo może być przedstawione w postaci nakładających się i przecinających kręgów zaufania, rozumianych jako kręgi ludzi, wśród których występuje zaufanie, wzajemność i współpraca. Kiedy zasięg danego kręgu zaufania ogranicza się do niewielkiej grupy, solidarność wewnątrzgrupowa wywołuje negatywne efekty zewnętrzne, polegające na obniżeniu zdolności członków tej grupy do współpracy z osobami z zewnątrz. Natomiast gdy zaufanie społeczne przekracza swym zasięgiem grupę macierzystą, wówczas wytwarzają się pozytywne ogólnospołeczne wartości.

Kontynuatorem koncepcji kapitału społecznego Colemana był Robert Putnam. Jego zdaniem (Putnam, 1995, s. 258-265) kapitał społeczny oznacza ogół norm społecznych, wzajemne zaufanie i więzi w grupie społecznej, które przyczyniają się do zwiększania skuteczności i sprawności działania społeczeństwa. Putnam zwrócił szczególną uwagę na wzajemną zależność kontaktów i zaufania. Zaufanie wzmacnia współpracę, a współpraca umacnia dalsze zaufanie, co tworzy pozytywne sprzężenie zwrotne. Co więcej, jak trafnie stwierdził Piotr Sztompka (2007, s. 256), wzajemne zaufanie może podlegać nie tylko samowzmacnianiu, ale także dziedziczeniu na przestrzeni kolejnych pokoleń.

W kolejnych badaniach Putnam (2008, s. 39-42) wykazał, że kapitał społeczny oparty na zaangażowaniu obywatelskim na rzecz dobra wspólnego nie jest jednak ani jedynym, ani stale obowiązującym modelem. Sieci współpracy obywa-

\footnotetext{
1 Pierwszym badaczem, który użył tego określenia, był Lawrence Harrison (1985, s. 7-8).
} 
telskiej, zwłaszcza w sferze gospodarczej, podtrzymywane są bowiem jedynie do czasu, kiedy przynoszą korzyści zainteresowanym stronom. Jest to także forma kapitału społecznego, ale oparta na sieci formalnych i nieformalnych kontaktów przedsiębiorców wymieniających usługi, informacje oraz doświadczenia.

Kapitał społeczny jest pojęciem wielowymiarowym, stąd też w literaturze (Diagnoza Społeczna, 2013; Kotarski, 2013; Działek, 2011; Bartkowski, 2007; Frykowski, Starosta, 2008; Fedyszak-Radziejowska, 2006) pojawia się wiele mniej czy bardziej dyskusyjnych wskaźników jego pomiaru (np. liczba organizacji pozarządowych; liczba członków organizacji, stowarzyszeń, partii, komitetów, rad, grup religijnych, związków lub kół; członkostwo w organizacjach religijnych i kościelnych; liczba wolontariuszy WOŚP; udział w nieprzymusowych zebraniach publicznych i zabieranie na nich głosu; frekwencja w wyborach lub referendach; odsetek osób, które odpisały w zeznaniu podatkowym kwoty przeznaczone na darowizny; liczba związków sportowych; członkowie klubów sportowych, zespołów artystycznych i kół zainteresowań; liczba imprez zorganizowanych przez ośrodki kultury, świetlice i kluby). Wykorzystywane są zarówno dane statystyczne gromadzone i przetwarzane przez różne instytucje, jak również dane z ogólnopolskich reprezentatywnych sondaży. Próby usystematyzowania licznych wskaźników podjęły się Maria Bednarek-Sczepańska (2013), Beata Łopaciuk-Gonczyrak (2012) i Katarzyna Sierocińska (2011). Autorki w swoich pracach wykazują, że w zależności od charakteru badanych zjawisk, przy konstruowaniu wskaźników syntetycznych uwzględniane są rozmaite zmienne, które opisują różne wymiary kapitału społecznego (np. zaufanie, sieci społeczne formalne i nieformalne) i analizowane są związki zachodzące między nimi. Jednocześnie badaczki słusznie zauważają, że dobór wskaźników powinien być uzależniony od charakterystyki badanej społeczności. Interesującym rozwiązaniem jest włączanie do badań ilościowych elementów badań jakościowych, co umożliwi lepsze zrozumienie analizowanych zjawisk, a co za tym idzie - ich bardziej wiarygodną operacjonalizację.

Ze względu na popularność niektórych mierników kapitału społecznego, a zwłaszcza biorąc pod uwagę cel i zakres niniejszego opracowania, szczególnie interesującymi są takie miary, jak: zaufanie (ogólne, do nieznajomych, określonych profesji i instytucji), przeświadczenie o możliwości oddziaływania na sprawy publiczne, działania wspólne na rzecz społeczności lokalnej, inicjowanie i dobrowolne uczestnictwo w akcjach społecznych, przynależność do różnych organizacji i instytucji, udział w wyborach władz. 


\section{FORMY KAPITAŁU SPOŁECZNEGO}

W literaturze przedmiotu za sprawą Putnama (2008, s. 40-41) rozróżnia się dwie podstawowe formy kapitału społecznego:

- kapitał wiążący (bonding) oparty na silnych więziach członków (jednostek) wewnątrz danej homogenicznej grupy społecznej;

- kapitał pomostowy (bridging) odpowiadający za budowę powiązań pomiędzy różnymi grupami czy społecznościami.

Kapitał wiążący przejawia się z jednej strony w silnych więziach członków małej grupy społecznej (rodzina, grupa etniczna), a z drugiej strony - w wykluczaniu osób, które do tej grupy nie należą. W takim przypadku postawy członków grupy wobec otoczenia i problemów gospodarczych są $\mathrm{w}$ minimalnym stopniu poparte racjonalną analizą, a w większym stopniu emocjami o charakterze defensywnym. Informacja krąży wewnątrz grupy, kontakt $\mathrm{z}$ odmiennymi ideami jest ograniczony, co blokuje wykorzystanie nowatorskich rozwiązań. Tę kategorię kapitału społecznego zwykle cechuje ekskluzywność (zamknięcie), nieufność wobec obcych prowadząca do nietolerancji. Wiążący kapitał społeczny sprzyja realizacji partykularnych celów określonych grup społeczeństwa. Jak zauważył Richard Rose (1998), badając rozwój społeczności w Rosji, w specyficznych warunkach społecznych i politycznych kapitał wiążący może przyjąć antymodernizacyjny charakter i stać się przeszkodą w rozwoju społeczeństwa.

Pomostowy kapitał społeczny odnosi się do relacji, jakie nawiązują między sobą członkowie różnych grup społecznych. Pomimo różnic w wyznawanych wartościach, nawiązywane kontakty sprzyjają mobilizacji i aktywizacji członków tych grup w ich wzajemnym, międzygrupowym działaniu, budowaniu społecznego zaufania i otwartości na pojawiające się wyzwania. Dlatego kapitał łączący ułatwia pracę zespołową, wspólne działania, wprowadzanie innowacji, społecznych zmian jakościowych i ogólny postęp.

Jakkolwiek obie formy kapitału społecznego różnią się, to jednak nie wykluczają, ponieważ relacje w określonych grupach społecznych mogą być jednocześnie łączące (inkluzywne) i wiążące (ekskluzywne). Wiążące powiązania służą jednostce, a powiązania pomostowe, choć są luźniejsze i bardziej ulotne, ułatwiają przepływ informacji oraz współpracę zarówno pomiędzy ludźmi, jak i grupami. Dlatego zdaniem badaczy kapitału społecznego (Bartkowiak, 2007; Guiso, Sapienza, Zingales, 2008) dla rozwoju społecznego korzystna jest równowaga pomiędzy wiążącymi a łączącymi powiązaniami społecznymi. 


\section{EFEKTY KAPITAŁU SPOŁECZNEGO}

Większość przytoczonych opracowań poświęconych zagadnieniom kapitału społecznego podkreśla głównie jego pozytywny wpływ na możliwości i działanie grup, instytucji oraz społeczności. Kapitał społeczny umożliwia współpracę różnych podmiotów oraz pełne synergiczne wykorzystanie zasobów, które one posiadają. Społeczeństwa cechujące się wysokim poziomem kapitału społecznego są lepiej zorganizowane i zarządzane, ludzie są zamożniejsi i zadowoleni z życia. Samoorganizacja często nieznających się wcześniej członków lokalnych i regionalnych społeczności, niezależnie od różnorodnych afiliacji rodzinnych czy kulturowych, umożliwia im optymalne wykorzystanie społecznej energii (talentów, wiedzy, zapału, doświadczenia, kontaktów, wreszcie zasobów materialnych i finansowych), nie zmusza bowiem ich członków do współpracy wyłącznie w ograniczonych ramach struktur narzuconych przez tradycję lub ustalonych przez formalną władzę.

Nie wszystkie badania potwierdzają dodatnie efekty kapitału społecznego. Alejandro Portes (1998, s. 16-18) wymienia cztery rodzaje negatywnego oddziaływania kapitału społecznego: wykluczenie, zbyt silny nacisk na członków zwartej grupy, ograniczenie ich indywidualnych swobód (wolności) i zaniżanie norm społecznych. Zdaniem Portesa ścisłe więzi mogą ograniczać osoby bardziej kreatywne oraz przyczyniać się do unikania kontaktów z obcymi. Aby zniwelować koszty zakorzenienia, silne więzi cechujące społeczności lokalne muszą być uzupełniane więziami autonomicznymi, czyli kontaktami członków wspólnoty z jednostkami spoza społeczności.

Według Johna Fielda (2003, s. 74) i Patricka Batesona (1988, s. 214) przejawem niekorzystnych skutków kapitału społecznego jest wysoki stopień lojalności oraz silne formalne i nieformalne więzi stanowiące podstawę tzw. brudnych wspólnot - różnego typu klik, układów, koterii, organizacji przestępczych. Jedną z najbardziej znanych ilustracji „brudnego” kapitału społecznego jest amoralny familizm, którego przykładem są stosunki społeczne mieszkańców południowych Włoch, bazujące na rodzinie i nieformalnych powiązaniach towarzyskich (Banfield, 1958). Do organizacji mających nierzadko negatywny wpływ na rozwój gospodarczy zaliczane są również związki producentów, związki zawodowe, korporacje zawodowe. Organizacje te walczą głównie o własne partykularne korzyści, kosztem interesu społecznego. Dążą do wprowadzenia korzystnego dla siebie prawa, uzyskania koncesji i zezwoleń, mając pełną świadomość, że koszty ich wdrażania ponosi całe społeczeństwo. 
Jak podkreślają również polscy badacze (Hausner, Marody, 2000; Jasiecki, 2013), niekorzystny wpływ tego rodzaju kapitału społecznego na gospodarkę cechuje także polityków, których poczucie przyzwoitości politycznej zastępuje się pragmatyzmem partyjnym, rozumianym jako dbanie o interesy swojej partii, partyjnych kolegów, zaprzyjaźnionych osób i środowisk. Taka praktyka wytworzyła poczucie bezkarności i korupcję rządzących polityków oraz funkcjonariuszy publicznych, zarówno na poziomie centralnym, jak i samorządowym. Podobnie system immunitetów zarówno parlamentarzystów, jak i prokuratorów oraz sędziów chroni ich przed odpowiedzialnością zarówno za pospolite naruszenia prawa (np. łamanie zasad kodeksu drogowego), jak również za negatywne efekty swojej działalności - nadużycia władzy i niedopełnienie obowiązków służbowych².

\section{PRZEDMIOT, METODOLOGIA I CEL BADANIA}

Badanie zostało przeprowadzone pod koniec 2014 r. przez Urząd Statystyczny w Kielcach na próbie badania BAEL ${ }^{3}$. Narzędziem badawczym była ankieta zawierająca łącznie z metryczką 31 pytań związanych z problematyką niniejszej pracy. Wyjściowa próba badawcza objęła 205 mieszkańców województwa świętokrzyskiego. Dobór próby był losowo-warstwowy, a jej reprezentatywność w stosunku do populacji polega na tym, że próba odzwierciedla procentowy udział poszczególnych grup objętych badaniem w strukturze ludności województwa świętokrzyskiego - w odniesieniu do miejsca zamieszkania (miasto, wieś), wieku, poziomu wykształcenia oraz płci. Podstawę wyliczeń stanowiły dane demograficzne za $2013 \mathrm{r}$. W rezultacie 54,6\% ankiet trafiło do respondentów zamieszkujących wieś, a 45,4\% - do osób zamieszkujących miasta. Zdecydowana większość ankietowanych mieszka we wskazanym miejscu od urodzenia, nie ukończyła 64 lat, ponad 44\% legitymuje się wykształceniem wyższym i ponadgimnazjalnym. Liczba przebadanych kobiet stanowi ponad

2 Przykładem tego typu zachowania było bezprawne zajęcie w listopadzie 2014 r. przez komornika z Łodzi ciągnika należącego do rolnika spod Mławy (Mazowieckie), mimo że rolnik ten nie miał długów. W podobny sposób dwoje przedsiębiorców z Sieradza i Gostynina straciło swoje auta. Mimo oczywistych nieprawidłowości izba komornicza nie dostrzegała negatywnych skutków tych przypadków w kształtowaniu społecznej akceptacji swojego środowiska.

3 Badanie to przeprowadzono w ramach projektu badawczego, realizowanego w Instytucie Nauk Politycznych Uniwersytetu Jana Kochanowskiego w Kielcach. 
54\%, a liczba mężczyzn - 46\% osób ankietowanych. Wielkości te nieco odbiegają od struktury ludności według płci, co spowodowane było większą niechęcią mężczyzn do udzielania wywiadów.

Tabela 1. Charakterystyka badanej grupy (w \%)

\begin{tabular}{|c|c|c|}
\hline \multirow{2}{*}{ Płeć } & Kobieta & 54,2 \\
\cline { 2 - 3 } & Mężczyzna & 45,8 \\
\hline \multirow{2}{*}{ Wiek } & $18-64$ & 78,1 \\
\hline \multirow{4}{*}{ Wykształcenie } & Powyżej 64 roku & 21,9 \\
\cline { 2 - 3 } & Wyższe & 18,5 \\
\cline { 2 - 3 } & Średnie & 25,9 \\
\cline { 2 - 3 } & Zawodowe & 33,2 \\
\hline \multirow{2}{*}{ Miejsce zamieszkania } & Podstawowe & 22,4 \\
\cline { 2 - 3 } & Miasto & 45,4 \\
\hline & Wieś & 54,6 \\
\hline
\end{tabular}

Źródło: opracowanie własne na podstawie badań.

Celem badania było rozpoznanie poziomu i struktury kapitału społecznego mieszkańców województwa świętokrzyskiego. Mając na uwadze realizację wyznaczonego celu badania, podjęto próbę odpowiedzi na pytania:

- jaki jest poziom zaufania mieszkańców województwa w wymiarze ogólnym, osobistym, pozycyjnym i instytucjonalnym,

- czy i w jakim stopniu mieszkańcy regionu angażują się społecznie,

- w jakim stopniu uczestniczą w życiu politycznym.

\section{WYNIKI BADANIA KAPITAŁU SPOŁECZNEGO MIESZKAŃCÓW WOJEWÓDZTWA ŚWIĘTOKRZYSKIEGO}

\section{Zaufanie ogólne}

W celu oceny poziomu uogólnionego zaufania poproszono ankietowanych mieszkańców o odniesienie się do stwierdzenia większości ludzi można ufać. $\mathrm{Z}$ udzielonych odpowiedzi wynika, że poziom uogólnionego zaufania badanych osób jest niski, ponieważ przekracza zaledwie 15\%; ostrożność w kontaktach 
z innymi i brak zaufania deklarowało $76,6 \%$ respondentów. Wyniki te są podobne do ustaleń innych badań ${ }^{4}$.

Tabela 2. Poziom zaufania ogólnego

\begin{tabular}{|c|c|c|c|c|}
\hline $\begin{array}{c}\text { Kategoria } \\
\text { oceny }\end{array}$ & $\begin{array}{c}\text { Większości można } \\
\text { zaufać }\end{array}$ & $\begin{array}{c}\text { Niektórym można } \\
\text { ufać }\end{array}$ & $\begin{array}{c}\text { Nie można } \\
\text { ufać nikomu }\end{array}$ & $\begin{array}{c}\text { Trudno } \\
\text { powiedzieć }\end{array}$ \\
\hline liczba odpowiedzi & 32 & 126 & 31 & 16 \\
\hline$\%$ & 15,6 & 61,5 & 15,1 & 7,8 \\
\hline
\end{tabular}

Źródło: opracowanie własne na podstawie badań.

Najwięcej respondentów jest skłonnych zaufać członkom rodziny $(88,3 \%$ wskazań) lub osobom, które dobrze znają (81,5\%). Zasadniczo mniej ankietowanych $(16,1 \%)$ uznało, że zaufać drugiej osobie można w sytuacji prawnego obowiązku dochowania tajemnicy przez drugą osobę lub gdy reprezentuje znaną instytucję publiczną (10,7\%). Tylko niespełna 4\% respondentów zaufałoby osobie, która należy do tej samej co ankietowany organizacji parafialnej lub grupy zainteresowań.

Tabela 3. Odpowiedź na pytanie, w jakiej sytuacji był(a)by Pan(i) bardziej skłonny(-na) zaufać drugiej osobie

\begin{tabular}{|c|c|c|c|c|c|}
\hline $\begin{array}{c}\text { Kategoria } \\
\text { oceny }\end{array}$ & $\begin{array}{c}\text { Gdy jest } \\
\text { członkiem } \\
\text { rodziny }\end{array}$ & $\begin{array}{c}\text { Gdy długo } \\
\text { znam tę } \\
\text { osobę }\end{array}$ & $\begin{array}{c}\text { W sytuacji prawnego } \\
\text { obowiązku dochowania } \\
\text { tajemnicy przez } \\
\text { drugą osobę }\end{array}$ & $\begin{array}{c}\text { Gdy należy do tej } \\
\text { samej organizacji } \\
\text { parafialnej }\end{array}$ & $\begin{array}{c}\text { Gdy reprezentuje } \\
\text { znaną instytucję } \\
\text { publiczną }\end{array}$ \\
\hline $\begin{array}{c}\text { liczba } \\
\text { odpowiedzi }\end{array}$ & 181 & 167 & 33 & 8 & 22 \\
\hline$\%$ & 88,3 & 81,5 & 16,1 & 3,9 & 10,7 \\
\hline
\end{tabular}

Źródło: opracowanie własne na podstawie badań.

4 Badanie regionalne z 2013 r., koordynowane przez Andrzeja Kościołka (2013), wykazało, że ponad $90 \%$ badanych mieszkańców województwa świętokrzyskiego deklarowało ostrożność w kontaktach z innymi. Trochę niższy poziom (około 88\%) deklarowanej ostrożności wobec innych osób wykazują ogólnopolskie badania (Europejski Sondaż Społeczny 2002-2012, CBOS, 2012). 


\section{Zaufanie w sferze prywatnej}

Zaufanie osobiste ankietowanych osób jest tym większe, im bliższe są ich relacje $\mathrm{z}$ określonymi w ankiecie grupami osób. Zrozumiałe jest więc, że zdecydowanie największym zaufaniem cieszą się członkowie najbliższej rodziny (82\%), a następnie przyjaciele $(44,4 \%)$. Z kolei zaskakująco niskie zaufanie występuje wśród koleżeństwa $\mathrm{z}$ pracy $(11,2 \%)$, a jeszcze niższe w stosunku do sąsiadów $(7,8 \%)$. Wykazane poziomy zaufania badanych, powstałe w relacjach z osobami najbliższymi, mogą być przejawem narastania niepożądanego wiążącego kapitału społecznego (familizmu).

Tabela 4. Osoby cieszące się największym zaufaniem ankietowanych

\begin{tabular}{|c|c|c|c|c|c|}
\hline $\begin{array}{c}\text { Kategoria } \\
\text { oceny }\end{array}$ & $\begin{array}{c}\text { Najbliższa } \\
\text { rodzina }\end{array}$ & $\begin{array}{c}\text { Przyjaciel/ } \\
\text { przyjaciółka }\end{array}$ & $\begin{array}{c}\text { Kolega/koleżan- } \\
\text { ka z pracy }\end{array}$ & Sąsiad/ka & $\begin{array}{c}\text { Trudno } \\
\text { powiedzieć }\end{array}$ \\
\hline $\begin{array}{c}\text { liczba } \\
\text { odpowiedzi }\end{array}$ & 168 & 91 & 23 & 16 & 9 \\
\hline$\%$ & 82,0 & 44,4 & 11,2 & 7,8 & 4,4 \\
\hline
\end{tabular}

Źródło: opracowanie własne na podstawie badań.

\section{Zaufanie do określonych profesji}

Dosyć często stosowaną miarą kapitału społecznego jest zaufanie pozycyjne odnoszone do przedstawicieli różnych grup społeczno-zawodowych. Wśród wskazanych grup dużym i średnim zaufaniem ankietowani obdarzyli żołnierzy (75,6\%), w następnej kolejności lekarzy $(71,8 \%)$, nauczycieli $(67,8 \%)$, policjantów $(61 \%)$ i księży $(56,1 \%)$. Niższym poziomem zaufania cieszą się sportowcy, prawnicy, bankowcy, dziennikarze i urzędnicy. Jak widać, respondenci najwyżej ocenili grupy zawodowe utożsamiane $\mathrm{z}$ wykonywaniem pracy polegającej na obronie, ochronie majątku, życia i zdrowia.

Z kolei największą nieufność wzbudzają politycy - aż 63,3\% ankietowanych im nie ufa. Zła opinia o politykach w Polsce w dużej mierze jest skutkiem kolejnych afer $\mathrm{z}$ udziałem działaczy partyjnych, niezależnie od rodzaju ugrupowania sprawującego władzę. Trudno się zatem dziwić opinii większości obywateli (62\% badanych w 2013 r.), że funkcjonowanie polityków i partii politycznych nie jest 
wolne od nepotyzmu i korupcji politycznej (CBOS, 2013; Czuchnowski 2012). Społeczeństwo dostrzega, że politycy nierzadko tworzą sieć powiązań służącą czerpaniu korzyści z państwowego majątku, mnożą stanowiska przydzielane z politycznego klucza, ułatwiają zlecenia dla firm prowadzonych przez osoby powiązane wspólnym interesem. Oprócz polityków wysoki poziom nieufności odnotowali także celebryci $(38,1 \%)$. Negatywny obraz tej grupy społecznej bierze się prawdopodobnie z przekonania, że dbają oni przede wszystkim o własny interes ekonomiczny i popularność w mediach: za odpowiednie wynagrodzenie angażują się w każdą formę działań marketingowych, reklam, niezależnie od rodzaju i uczciwości promowanych sugestii oraz ich skutków ogólnospołecznych. Stosunkowo wysoką nieufnością respondenci obdarzyli także duchownych, bankowców, urzędników i prawników (około 15\%). Udzielone odpowiedzi są zbieżne z ogólnoeuropejskim badaniem zaufania do grup zawodowych (Rider's Digest, 2014).

Tabela 5. Poziom zaufania do grup zawodowych ( $w \%$ )

\begin{tabular}{|l|c|c|c|c|c|}
\hline $\begin{array}{l}\text { Grupa } \\
\text { zawodowa }\end{array}$ & $\begin{array}{c}\text { Duże } \\
\text { zaufanie }\end{array}$ & Średnie zaufanie & $\begin{array}{c}\text { Małe } \\
\text { zaufanie }\end{array}$ & $\begin{array}{c}\text { Brak } \\
\text { zaufania }\end{array}$ & $\begin{array}{c}\text { Trudno } \\
\text { powiedzieć }\end{array}$ \\
\hline Polityk & 1,5 & 10,7 & 21,5 & 63,4 & 2,9 \\
\hline Lekarz & 22 & 49,8 & 19 & 3,9 & 5,4 \\
\hline Ksiądz & 19 & 37,1 & 23,9 & 15,1 & 4,9 \\
\hline Prawnik & 11,2 & 30,7 & 22,4 & 12,7 & 22,9 \\
\hline Urzędnik & 6,3 & 38,5 & 27,8 & 14,6 & 12,7 \\
\hline Nauczyciel & 23,4 & 44,4 & 13,2 & 3,9 & 15,1 \\
\hline Sportowiec & 13,7 & 32,2 & 8,8 & 6,8 & 38,5 \\
\hline Dziennikarz & 8,3 & 32,2 & 16,6 & 21 & 22 \\
\hline Bankowiec & 9,3 & 29,8 & 23,9 & 14,6 & 22,4 \\
\hline Żołnierz & 27,3 & 48,3 & 5,4 & 3,4 & 26,3 \\
\hline Policjant & 12,7 & 48,3 & 15,6 & 7,3 & 16,1 \\
\hline Celebryta & 1 & 3,9 & 6,8 & 38,1 & 50,2 \\
\hline
\end{tabular}

Źródło: opracowanie własne na podstawie badań. 


\section{Zaufanie do instytucji życia publicznego}

Zaufanie instytucjonalne jest odzwierciedleniem stosunku społeczeństwa do państwa i działających w nim instytucji oraz organizacji. Decydujący wpływ na poziom zaufania do instytucji publicznych ma jakość i stabilność regulacji prawnych, przejrzystość, sprawność i skuteczność działania władzy publicznej, zakres wolności i obowiązków obywateli, kultura organizacji. Społeczeństwa charakteryzujące się wysokim zaufaniem do instytucji łatwiej podporządkowują się decyzjom administracji publicznej, chętniej przestrzegają prawo i normy obyczajowe. Z drugiej strony, zinstytucjonalizowana nieodpowiedzialność, niedostatki w ustawodawstwie, nieskuteczność w egzekwowaniu prawa, atmosfera nieprzewidywalności zachowań, partyjna kolonizacja instytucji publicznych, arbitralność urzędniczych decyzji oraz pasywność w rozwiązywaniu problemów nurtujących społeczeństwo w znacznym stopniu osłabiają zaufanie instytucjonalne. W takiej sytuacji, gdy obywatel nie ufa państwu, a państwo nie ufa obywatelowi, wytwarza się mechanizm błędnego koła nieufności, blokujący rozwój społeczno-gospodarczy.

Wśród wskazanych instytucji zdecydowanie największym zaufaniem ankietowanych cieszą się: szkoły $(79,5 \%)$, szpitale $(77,6 \%)^{5}$, wojsko $(75,6 \%)$, a następnie policja (67,8\%), Kościół $(67,4 \%)$ i władza samorządowa (62\%). Natomiast niski poziom zaufania lub wręcz jego brak ankietowani deklarują wobec partii politycznych $(76,1 \%)$, rządu $(75,6 \%)$, Sejmu (71,8\%), a następnie Parlamentu Europejskiego $(55,1 \%)$. Stosunkowo wysoki poziom nieufności wśród respondentów wzbudzają banki (36,6\%), sądy (35,6\%), władza samorządowa (34,6\%), a także Kościół (28,3\%). Przedstawione wyniki są w dużej mierze zbieżne z rezultatami badań ogólnopolskich i międzynarodowych (CBOS, 2015; Rajca, 2012, s. 195-196).

5 Jest to stosunkowo wysoki wskaźnik, zważywszy na powszechnie znane słabości systemu opieki zdrowotnej w naszym kraju, które zostały wykazane w badaniu Health\&Society Barometer (2014). Spośród 9. badanych krajów polska opieka medyczna została oceniona najgorzej. 
Tabela 6. Poziom zaufania instytucjonalnego ( $\mathrm{w} \%)$

\begin{tabular}{|l|c|c|c|c|c|}
\hline Instytucje & Wysoki & Średni & Niski & Brak & Trudno powiedzieć \\
\hline Partia polityczna & 1 & 11,2 & 27,8 & 48,3 & 11,7 \\
\hline Sejm & 1 & 16,6 & 34,2 & 37,6 & 10,7 \\
\hline Rząd & 1 & 15,1 & 40 & 35,6 & 8,3 \\
\hline Parlament Europejski & 3,4 & 22,4 & 30,7 & 24,4 & 19 \\
\hline $\begin{array}{l}\text { Wójt/burmistrz/ } \\
\text { prezydent }\end{array}$ & 12,2 & 49,8 & 24,4 & 10,2 & 3,4 \\
\hline Sąd & 11,7 & 42,4 & 28,3 & 7,3 & 10,2 \\
\hline Policja & 12,7 & 55,1 & 20 & 6,3 & 5,9 \\
\hline Wojsko & 31,7 & 43,9 & 6,8 & 2,4 & 15,1 \\
\hline Szkoła & 30,2 & 49,3 & 8,8 & 2 & 9,8 \\
\hline Szpital & 22 & 55,6 & 13,2 & 3,4 & 5,9 \\
\hline Kościół & 29,3 & 38,1 & 12,7 & 15,6 & 4,4 \\
\hline Bank & 8,8 & 47,8 & 25,9 & 10,7 & 6,8 \\
\hline Organizacja pozarządowa & 10,2 & 18,1 & 11,7 & 7,3 & 52,7 \\
\hline
\end{tabular}

Źródło: opracowanie własne na podstawie badań.

\section{Ocena czynników wpływających na rozwiązanie} problemów życiowych

Niskiemu zaufaniu do instytucji publicznych towarzyszy przekonanie o ograniczonym wpływie czynników merytorycznych warunkujących znalezienie zatrudnienia. Prawie 65\% ankietowanych stwierdziło, że o zdobyciu pracy decydują przede wszystkim koligacje rodzinne i układy towarzyskie, w następnej kolejności poparcie polityków (łącznie 48,3\% wskazań). Symptomatyczne jest to, że ponad połowa respondentów deprecjonuje znaczenie doświadczenia zawodowego w znalezieniu pracy, a zdaniem 63\% respondentów świadectwo ukończenia dobrych studiów nie stanowi silnego atutu na rynku pracy. Wskazania w tym względzie nie odbiegają od wyników innych badań z 2014 r.; według raportu przygotowanego przez Work Service (2014) najbardziej skutecznym sposobem na znalezienie pracy w naszym kraju jest wykorzystanie znajomości i stosunków rodzinnych (73\% wskazań) i nawet najlepiej wykształcone jednostki, bez pomocy innych, niewiele osiągną na rynku pracy. 
Tabela 7. Czynniki decydujące o zatrudnieniu (w \%)

\begin{tabular}{|l|c|c|c|c|}
\hline Kategoria oceny & Bardzo ważne & Ważne & Mało ważne & Bez znaczenia \\
\hline Poparcie polityków & 28,3 & 20 & 11,2 & 40,5 \\
\hline Poparcie rodziny lub znajomych & 34,2 & 30,7 & 26,8 & 8,3 \\
\hline Wiedza i doświadczenie zawodowe & 23,4 & 26,3 & 31,2 & 19 \\
\hline Dyplom dobrej uczelni & 14,2 & 22,9 & 30,2 & 32,7 \\
\hline
\end{tabular}

Źródło: opracowanie własne na podstawie badań.

Przy tak ocenianych szansach na rynku pracy trudno się dziwić, że dla sporej części osób objętych badaniem nie ma większego znaczenia, w jaki sposób zostanie osiągnięty cel zawodowy: czy własnymi siłami, przy wsparciu rodziny, znajomych lub polityków. Co trzeci $(35,1 \%)$ ankietowany deklarował, że zdarzyło mu się rozwiązać jakąś trudną sprawę życiową dzięki osobistym znajomościom. Wyniki te wskazują na sytuację, że grupa ta jest skłonna tolerować nepotyzm i kumoterstwo. Z drugiej strony pozytywnie należy ocenić, że ponad 39\% respondentów nie potrzebowało czyjejś pomocy przy rozwiązywaniu osobistych problemów, a około 25\% rzadko z niej korzystało.

Tabela 8. Rozwiązanie trudnej sytuacji życiowej dzięki osobistym znajomościom

\begin{tabular}{|c|c|c|c|c|}
\hline Kategoria oceny & Tak, często & Tak, czasami & Rzadko & Nigdy \\
\hline liczba & 9 & 63 & 52 & 81 \\
\hline$\%$ & 4,4 & 30,7 & 25,4 & 39,5 \\
\hline
\end{tabular}

Źródło: opracowanie własne na podstawie badań.

\section{Zaangażowanie społeczne}

Ankietowane osoby raczej nie wierzą we własną sprawczość. Zaledwie 23,9\% z nich ma silne poczucie wpływu na kształtowanie sytuacji w najbliższym otoczeniu. Niewysokie przekonanie respondentów o możliwości wpływu na sprawy lokalne nie sprzyja ich świadomej i aktywnej współpracy z władzami samorządowymi na rzecz wypracowania i realizacji celów publicznych. Zdecydowana większość ankietowanych $(65,4 \%)$ nie uczestniczyła w spotkaniach z władzami lokalnymi w sprawie rozwoju miasta lub gminy, a tylko co czwarty respondent potwierdził udział w takich spotkaniach. Niskie zaangażowanie społeczne miesz- 
kańców województwa świętokrzyskiego potwierdzają ogólnokrajowe badania (Diagnoza Społeczna, 2014, s. 304). Wskazują one, że w świętokrzyskim wskaźnik wrażliwości na dobro publiczne na poziomie 2,61 jest jednym $\mathrm{z}$ najniższych w kraju. Niewielkie zainteresowanie ankietowanych udziałem w spotkaniach $\mathrm{z}$ władzą lokalną prawdopodobnie wynika $\mathrm{z}$ często fasadowego charakteru takich spotkań, których wyniki i tak nie mają istotnego wpływu na decyzje podejmowane przez władze. Opinia społeczna wyrażana podczas takich spotkań jest często po prostu ignorowana, co świadczy o niskim poziomie świadomości władz o istocie konsultacji i postrzeganiu ich jako wymogu proceduralnego, a nie wyrazu woli obywateli.

Tabela 9. Odpowiedź ankietowanych na pytanie, czy brał(a) Pan(i) udział w spotkaniu z udziałem mieszkańców

i władz lokalnych dotyczącym spraw gminy lub miasta

\begin{tabular}{|c|c|c|c|}
\hline Kategoria oceny & Tak & Nie & Nie pamiętam \\
\hline liczba & 51 & 134 & 20 \\
\hline$\%$ & 24,9 & 65,4 & 9,8 \\
\hline
\end{tabular}

Źródło: opracowanie własne na podstawie badań.

Badani wykazują również stosunkowo niską aktywność społeczną rozumianą jako dobrowolną i nieodpłatną pracę na rzecz swojej okolicy lub pomoc osobom potrzebującym spoza kręgu rodziny i znajomych. Taką aktywność deklarował tylko co piąty badany, a aż $80,5 \%$ z nich przyznało, że nie poświęciło czasu na tego typu aktywność ani razu. Jest to wyraźnie niższa aktywność społeczna mieszkańców województwa świętokrzyskiego w porównaniu z poziomem zaangażowania społecznego w skali kraju (CBOS, 2011, s. 1).

Tabela 10. Odpowiedź ankietowanych na pytanie, czy kiedykolwiek podjął(-jęła) Pan(i) dobrowolną i bezpłatną pracę na rzecz potrzebujących, wsi, gminy

\begin{tabular}{|c|c|c|}
\hline Kategoria oceny & Tak & Nie \\
\hline liczba & 40 & 165 \\
\hline$\%$ & 19,5 & 80,5 \\
\hline
\end{tabular}

Źródło: opracowanie własne na podstawie badań. 


\section{Troska o dobro wspólne}

Społeczna postawa ludzi wyraża się także w formie zainteresowania bieżącymi sprawami dobra wspólnego: kontaktowaniem się z władzą publiczną, mediami czy policją w jakiejś ważnej lokalnie sprawie (ostrzeganiem o problemach, informowaniem o niepożądanej sytuacji, naruszeniu prawa, przejawach przemocy). Takie zachowania sprzyjają skuteczności władz publicznych oraz bezpieczeństwu i porządkowi publicznemu, w konsekwencji przyczyniają się do poprawy jakości życia. Postawy ankietowanych mieszkańców w tej kwestii nie napawają optymizmem: 78\% respondentów nie stwierdziła konieczności powiadomienia mediów lub publicznych instytucji o zaobserwowanym problemie. Ta forma aktywności i kontroli społecznej nie jest popularna, prawdopodobnie wynika z negatywnych wcześniejszych doświadczeń w tym zakresie lub kojarzy się ze zwykłym donosicielstwem. Zaledwie 16,1\% badanych uznało, że taka aktywność jest obywatelskim obowiązkiem.

Tabela 11. Odpowiedź ankietowanych na pytanie, czy kiedykolwiek informował(a) Pan(i) prasę, radio, policję, władze miasta lub gminy o stwierdzonym problemie (ustnie lub pisemnie)

\begin{tabular}{|c|c|c|c|}
\hline Kategoria oceny & Tak & Nie & Nie pamiętam \\
\hline liczba & 33 & 160 & 12 \\
\hline$\%$ & 16,1 & 78,0 & 5,9 \\
\hline
\end{tabular}

Źródło: opracowanie własne na podstawie badań.

\section{Aktywność obywatelska}

Relatywnie mała aktywność w niesieniu pomocy innym, zdiagnozowana wśród badanych mieszkańców, przekłada się na ich niskie zainteresowanie działalnością organizacji powołanych w tym celu. Prawie $83 \%$ respondentów miało problemy z wymienieniem choćby jednej tego typu organizacji społecznej działającej na poziomie lokalnym. Zaledwie $17,7 \%$ zetknęło się z organizacjami pozarządowymi działającymi w ich miejscu zamieszkania. Najczęściej wymieniano takie organizacje, jak: koła gospodyń wiejskich, stowarzyszenia emerytów, straż pożarną. Ten stosunkowo niski poziom zaangażowania obywatelskiego ankietowanych, utrudniający budowanie społeczeństwa obywatelskiego i kształtowanie społecz- 
nego dobrobytu, może być rezultatem mniej wykszatłconych form aktywności organizacji charytatywnych i wolontariatu w województwie świętokrzyskim niż w regionach bardziej zurbanizowanych ${ }^{6}$.

Tabela 12. Znajomość organizacji pozarządowych działających na poziomie lokalnym

\begin{tabular}{|c|c|c|}
\hline Kategoria oceny & Tak & Nie \\
\hline liczba & 35 & 170 \\
\hline$\%$ & 17,7 & 82,9 \\
\hline
\end{tabular}

Źródło: opracowanie własne na podstawie badań.

\section{Udział w życiu politycznym}

Ważnym wskaźnikiem postaw obywatelskich i ogólnie uczestnictwa w życiu publicznym jest udział w wyborach władz różnego szczebla. Jak wynika z udzielonych odpowiedzi, największe znaczenie badani (60\% wskazań) przypisują wyborom przedstawicieli do władz lokalnych. Tak wysoki poziom deklarowanej aktywności wyborczej znajduje potwierdzenie w najwyższej w kraju frekwencji wyborczej w województwie świętokrzyskim w wyborach samorządowych $2014^{7}$. Na duże zainteresowanie wyborami samorządowymi wskazuje także inna analiza (Trutkowski, Kurniewicz, 2015), z której wynika, że im mniejsza jednostka samorządowa, tym więcej mieszkańców bierze udział w głosowaniu. Przyczyn takiego stanu rzeczy należy upatrywać nie tylko w oddolnej potrzebie mieszkańców decydowania o wyborze najbardziej odpowiednich władz, ale prawdopodobnie także w wysokiej aktywności lokalnych działaczy politycznych osobiście zainteresowanych ochroną swoich miejsc pracy w administracji samorządu terytorialnego. Często ich miejsca pracy są wykorzystywane jako ogniwa sztabów wyborczych (Radwan 2015). Znacznie mniejsze zainteresowanie wśród ankietowanych osób wzbudzają wybory do Parlamentu Europejskiego

\footnotetext{
6 Pod względem aktywności obywatelskiej wyrażonej wskaźnikiem liczby fundacji, stowarzyszeń i innych organizacji społecznych w przeliczeniu na 10 tysięcy mieszkańców region plasuje się na 13. miejscu w kraju.

7 Frekwencja w wyborach samorządowych w 2014 r. w województwie świętokrzyskim wyniosła 53,29\% uprawnionych do głosowania, podczas gdy w kraju 47,4\%. http://pkw.gov.pl/obwieszczenia-i-komunikaty-samorzad-2014/ (dostęp: 29.10.2015).
} 
(42,4\% wskazań). Wynika to przede wszystkim z tego, że działalność PE nie ma bezpośredniego wpływu na życie mieszkańców, stąd ich niewielka wiedza i zainteresowanie rolą i kompetencjami tej unijnej instytucji.

Tabela 13. Deklarowany udział w wyborach

\begin{tabular}{|c|c|c|c|c|}
\hline \multirow{2}{*}{$\begin{array}{c}\text { Kategoria } \\
\text { oceny }\end{array}$} & \multicolumn{2}{|c|}{ Do samorządu terytorialnego } & \multicolumn{2}{c|}{ Do Parlamentu Europejskiego } \\
\cline { 2 - 5 } & Tak & Tak & Tak & Nie \\
\hline liczba & 123 & 82 & 87 & 82 \\
\hline$\%$ & 60 & 40 & 42,4 & 40 \\
\hline
\end{tabular}

Źródło: opracowanie własne na podstawie badań.

\section{PODSUMOWANIE}

Przeprowadzone badanie wykazało, że ankietowanych mieszkańców województwa cechuje wysoki poziom wiążącego kapitału społecznego, a stosunkowo niski - kapitału pomostowego. Respondenci obdarzają zaufaniem niemal wyłącznie członków rodziny i najbliższych znajomych, dlatego wykazują dość duże zrozumienie dla wstawiennictwa, protekcji, kumoterstwa i w gruncie rzeczy nepotyzmu. W ich opinii znajomość polityków oraz osób wpływowych jest ważniejsza niż zdobyte wykształcenie oraz doświadczenie zawodowe. Stosunkowo niski ogólny brak zaufania ankietowanych do innych ludzi, niektórych grup zawodowych i instytucji wiąże się z przekonaniem o zachowaniu ostrożności w relacjach z nimi. Dlatego niespecjalnie dziwi fakt, że osoby objęte badaniem za najbardziej skuteczne uznały działania nieformalne i nieoficjalne, co z kolei często narusza reguły uczciwej konkurencji na rynku i zakłóca ład demokratyczny w życiu publicznym. Poza tym takie zachowania sprzyjają narastaniu nieufności do uczciwości i pomocniczości władz oraz instytucji publicznych, do rzetelności m.in. prowadzonych konkursów w sprawie naborów do pracy czy postępowań przetargowych o udzielenie zamówienia publicznego.

Badanie wykazało, że przekonaniom ankietowanych o potrzebie wpływu na wybory władz publicznych nie towarzyszy gotowość do świadomej i aktywnej współpracy z tymi władzami na rzecz rozwoju regionalnego. Niewielu respondentów jest skłonnych interweniować i powiadamiać właściwe instytucje o naruszeniu porządku lub występującym zagrożeniu. Niepokojące jest również stosunkowo niewielkie zainteresowanie badanych zorganizowanymi formami 
aktywności obywatelskiej, tworzącymi strukturę instytucjonalną pośredniczącą pomiędzy rodziną i władzą publiczną. Wydaje się, że w niemałej mierze odpowiadają za to władze publiczne różnych szczebli, które zbyt rzadko zachęcają obywateli do współpracy oraz czynnego udziału w ważnych dla rozwoju lokalnego inicjatywach i działaniach.

Zarysowany obraz kapitału społecznego mieszkańców województwa świętokrzyskiego wymaga kolejnych, pogłębionych badań nad przyczynami przedstawionych postaw i zachowań. Pełna identyfikacja i klasyfikacja czynników blokujących społeczny kapitał rozwoju województwa świętokrzyskiego umożliwi podjęcie przez władze publiczne niezbędnych działań, które mogą przyczynić się do podniesienia poziomu ogólnego zaufania mieszkańców regionu, zwiększenia ich chęci do współdziałania społecznego oraz partycypacji obywatelskiej. Współcześnie, kiedy przewagę nad ilościowymi czynnikami rozwoju zyskały czynniki jakościowe (Pastuszka, 2009), odpowiedni poziom pomostowego kapitału społecznego ułatwi rozwój gospodarki regionalnej opartej na wiedzy, przyczyni się do przyspieszenia postępu społecznego województwa świętokrzyskiego, a w efekcie do zwiększenia dobrobytu mieszkańców regionu.

\section{BiBLIOGRAFIA:}

Aktywność społeczna mieszkańców województwa świętokrzyskiego - diagnoza społeczeństwa obywatelskiego (2013). Kielce.

Aktywność społeczna Polaków - poziom zaangażowania i motywacje. (2011).Warszawa: CBOS, BS/62.

Banfield, E.C. (1958). The Moral Basis of a Backward Society, New York: Free Press.

Barometr rynku pracy. Edycja druga. (2014). Work Service.

Bartkowski, J. (2007). Kapitał społeczny i jego oddziaływanie na rozwój w ujęciu socjologicznym. W: M. Herbst (red.). Kapitał ludzki i kapitał społeczny a rozwój regionalny (s. 54-97). Warszawa: Wydawnictwo Naukowe Scholar.

Bateson, P. (1988). The Biological Evolution of Cooperation and Trus. W: D. Gambetta. Making and Breaking of Cooperative Relations. New York: Basil Blackwell.

Bednarek-Sczepańska, M. (2013). Zróżnicowanie przestrzenne kapitału społecznego w Polsce - ujęcie przeglądowe. Przegląd Geograficzny, nr 85/4, s. 573-597.

Bourdieu, P. (1986). The forms of capital. W: J.G. Richardson (red.), Handbook of theory and research for the sociology of education (s. 241-258). New York/Westport/ London.

Coleman, J. (1988). Social capital in the creation of human capital. American Journal of Sociology, t. 94, s. 95-120.

Coleman, J. (1990). Foundations of social theory, Cambridge: Harvard University Press. 
Czapiński, J. (2006). Polska - państwo bez społeczeństwa. Nauka nr 1.

Czuchnowski, W. (2012). Sami swoi na państwowym, czyli jak partie dzielą posady. Gazeta Wyborcza, nr 176.

Diagnoza Społeczna 2013. Warunki i jakość życia Polaków. Raport (2014). J. Czapiński, T. Panek (red.).Warszawa: Ministerstwo Pracy i Polityki Społecznej, Centrum Rozwoju Zasobów Ludzkich.

Działek, J. (2011). Kapitał społeczny - ujęcie teoretyczne i praktyka badawcza. Studia Regionalne i Lokalne, nr 3(45), s. 100-118.

Fedyszak-Radziejowska, B. (2006). Czy kapitał społeczny bez społecznego zaufania jest możliwy? W: K. Szafraniec (red.). Jednostkowe i społeczne zasoby wsi (s. 123-146). Warszawa: IRWiR PAN.

Field, J. (2003). Social Capital. London: Routledge.

Frykowski, M., Starosta, P. (2008). Kapitał społeczny i jego użytkownicy. Przegląd Socjologiczny, t. 57 (1), s. 53-55.

Fukuyama, F. (1997). Zaufanie: kapitał społeczny a droga do dobrobytu. Warszawa Wrocław: Wydawnictwo Naukowe PWN.

Guiso, L., Sapienza, P., Zingales, L. (2008). Social Capital as Good Culture. Journal of the European Economic Association, t. 6/2-3, s. 295-320.

Harrison, L. (1985). Underdevelopment in State of Mind: The Latin American Case, New York 1985: Madison Books.

Hausner, J., Marody, M. (2000). Jakość rządzenia: Polska bliżej Unii Europejskiej? Kraków-Warszawa: MSAP AE i Fundacja im. F. Eberta.

Jasiecki, K. (2013). Kapitalizm po polsku. Między modernizacja a peryferiami Unii Europejskiej, Warszawa: Wydawnictwo IFiS PAN.

Kotarski, H. (2013). Kapitał ludzki i społeczny a rozwój województwa podkarpackiego. Rzeszów: Wydawnictwo Uniwersytetu Rzeszowskiego.

Lekarze w badaniach opinii społecznej w 2013 roku (2014). Warszawa: Ośrodek Studiów, Analiz i Informacji.

Łopaciuk-Gonczyrak, B. (2012). Mierzenie kapitału społecznego. Gospodarka Narodowa, $n r$ 1-2, s. 9-15.

Marki, które darzysz zaufaniem (2014). Warszawa: Rider's Digest.

North, D. (1990). Institutions, Institutional Change and Economic Performance. New York: Cambridge.

Polska-Europa. Wyniki Europejskiego Sondażu Społecznego 2002-2012 (2014).Warszawa.

Oceny instytucji publicznych (2015). Warszawa: CBOS, nr 21.

Opinie o korupcji w Polsce (2013). Warszawa: CBOS, BS/105.

Pastuszka, S. (2009). Uwarunkowania rozwoju regionalnego. Przegląd koncepcji teoretycznych. Wrocławskie Studia Politologiczne, nr 10, s.132-153.

Portes, A. (1998). Social Capital: Its Origins and Applications in Modern Sociology. Annual Review of Sociology, t. 24, s. 1-24.

Putnam, R. (1995). Demokracja $w$ działaniu. Tradycje obywatelskie we współczesnych Włoszech. Znak: Kraków. 
Putnam, R. (2008). Samotna gra w kręgle. Upadek i odrodzenie wspólnot lokalnych $w$ Stanach Zjednoczonych. Warszawa: Wydawnictwa Akademickie i Profesjonalne. Radwan, A. (2015). Trzy czwarte urzędników z nadania politycznego. Dziennik Gazeta Prawna, nr 161 (4054).

Rajca, L. (2012). Reformy samorzadu terytorialnego w Anglii w latach 1997-2010. Toruń. Rose, R. (1998). Getting things done in an Anti-Modern Society: Social Capital Networks in Russia. Social Capital Intiative Working Paper, The World Bank, no. 6. Sierocińska, K., (2011). Kapitał społeczny. Definiowanie, pomiar, typy. Studia Ekonomiczne, $n r 1$ (68), s. 69-86.

Sztompka, P. (2007). Zaufanie. Fundament społeczeństwa. Znak: Kraków.

Trutkowski, C., Kurniewicz, A. (2015). Bilans kadencji 2010-2014 w świetle wyników wyborów samorządowych. Najważniejsze wnioski. Fundacja Rozwoju Demokracji Lokalnej.

Williamson, O. (1998). Ekonomiczne instytucje kapitalizmu. Warszawa: Wydawnictwo Naukowe PWN.

Zaufanie społeczne (2012). Warszawa: CBOS. 